\title{
Chapter 4 \\ On the Use of Visual Methods \\ to Understand Local Immigration Politics
}

\author{
Amandine Desille
}

\subsection{Introduction}

Non-textual ways of communication have always taken up a substantial part of the geographer's toolbox: "photographs, aerial photographs, satellite images, maps and the application of GIS and GPS, so-called "geomatics" (Thornes, 2004, p. 787), are taken for granted in academic geographical practice today" (Schlottmann \& Miggelbrink, 2009, p. 1). Beside these representations of space, stills and moving images have also been produced in very early geographical works relating to everyday lives, place, housing, urban development and identity. American filmmaker Robert Joseph Flaherty, best known for his pioneering documentary Nanook of the North (1922), was himself a fellow of the Royal Geographical Society. The popularity of images has grown further recently (Burgess \& Gold, 2015; Cresswell \& Dixon, 2002; Kennedy \& Lukinbeal, 1997) and human geographers have too participated in the structuration of the "visual" as a field of study, supporting an interdisciplinary, participatory and critical $^{1}$ agenda (Hawkins, 2018). New technologies, their lower cost and friendly-use, and the democratization of practices have therefore pushed visual methodologies forward, generating new practices beyond maps and aerial photographs. This chapter, although based on a research project developed within geography, contributes to this interdisciplinary agenda. As reiterated in the

\footnotetext{
${ }^{1}$ Visual ethnography, at its beginnings, was associated with the colonial project (Pink, 2006, p. 5). Even though this seems in the past, Pink has observed that "Some recent publications on visual methods have (misguidedly) set out to discredit contemporary visual anthropology through criticism of its colonial roots and the observational projects of its mid-twentieth-century past (for example Smith et al., 2000; Holliday 2001)" (Pink, 2006, p. 15).
}

\footnotetext{
A. Desille $(\triangle)$

Institute of Geography and Spatial Planning, Universidade de Lisboa, Lisbon, Portugal
} 
introduction of this volume, the focus on people who have experienced migration makes more sense here, than the disciplinary internal debate on the visual.

With the broader adoption of visual methodologies, producers of still and moving images find themselves in an already overcrowded visual landscape. In geography and other disciplines that address international migrations, the need to consider the impacts of visual production has become even more acute during the crossMediterranean migrations that have reached unmatched media attention in Europe from 2015 on. Consequently, three sets of questions, often actualized (Raulin et al., 2016), have reemerged: one associated with positionality, reflexivity and interpretation; the second, related to ethics; and the third is concerned with participation, collaboration with participants to the research, and reciprocity in general.

In this chapter, I will present the making of an ethnographic film, ${ }^{2}$ which I filmed during a research project in geography carried out from 2013 to 2017 and entitled Victory Day. Hence, the project hereby referred to is a "researcher-created" or "researcher-initiated" production of visual data (Ball \& Gilligan, 2010; Pauwels, 2010). The footage was taken mostly in the street or in public buildings. As Raulin et al. have argued, at the moment when we take shots of actors of street performances "what reciprocity did we establish with them? Furthermore, what did we show, what was the part of interpretation through the photographer's eye? What social or ethnic invisibility were we entitled to denounce, what to make readable, how to make visible without stigmatizing?" (2016, p. 71). ${ }^{3}$ Bearing in mind this objective -"How to make visible without stigmatizing?"-, I would like to offer some preliminary answers with regards to the production of moving images, in particular when this production takes place in marginal places and involves the participation of persons who have experienced immigration.

The first section of the chapter will address the national context of the filmmaking, Israel, and its implication for the planning of the film. The second section will describe more in detail the conditions of the shooting, and the "sensory experiences" recorded and collected. Moreover, in this section and the one that follows, I hope to show that the use of the camera helped to grasp the complexity of the participants" experiences, the way they interact with one another within the place they inhabit, in a deeper way than traditional collection methods would have permitted. The fourth section focuses on the editing and montage process, and the choices I have made to tell the stories I recorded. Notably, I will address the shortcomings of Victory Day to introduce the larger context to an audience unfamiliar with Israeli periphery and with its immigrant residents. The last section describes the reactions of the participants, as well as the reactions of a broader academic audience when the film was screened.

With this piece, I hope to contribute to several points this book wishes to address. As a matter of fact, the chapter provides a reflection on the use of film to capture political actions, specifically the ones targeting immigrant groups. Secondly, it

\footnotetext{
${ }^{2}$ I published a piece in the francophone journal e-migrinter in September 2019 on similar thoughts. However, this chapter is not a translation of this piece.

${ }^{3}$ Author's translation. The original quote is: "Dès lors, quelle réciprocité instaurer avec ces acteurs de street performance? En outre, que donnait-on à voir, quelle était la part de l'interprétation par le regard du photographe? Quelle invisibilité sociale ou ethnique était-on en droit de dénoncer, que rendre lisible, comment rendre visible sans stigmatiser?" (Raulin et al., 2016, p. 71)
} 
shows the extent to which filmmaking relates to experiences of the participants involved, and to the sensorial experience of a place. With this, it builds on previous works that have highlighted the potential of moving images to represent the sensory, experiences and intersubjectivities (including Rouch, 1978; Gibson, 1979; MacDougall, 1998; Pink, 2009; Ferrarini, 2017). Thirdly, it tackles the ethics of working in conflict cities, and even more specifically, when participants take a hawkish stand in that conflict.

\subsection{Filming in Israel}

For scholars working in places where migrations represent a substantial or disruptive social phenomenon, or working in places enduring conflict or violence, the production of moving images usually takes place in a visually overcrowded space and raises constant ethical questions. As a point of fact, how could I avoid participating in the "spectacle" of migration (De Genova, 2013; Debord, 1967), or of the conflict that took place in Israel and Palestine? I had to engage with a reflexive process to overcome this issue and produce images diligently.

A first solution was to inquire outside of the large urban centers of Jerusalem and Tel Aviv. In the project I undertook at the time, I meant to conduct research in "ordinary cities" (Robinson, 2006), which meant to acknowledge the relevance of smaller cities, located outside of political, economic and socio-cultural networks, when conducting research. This had implications for the shooting of a film, and I aimed at producing images in a place that was usually invisible, and where media production was marginal. The film was thought to convey sensory experiences, in order to render the invisible seen and heard. Even if my intention was to distance myself from mainstream media, engaging with participants with a camera bore some risks. In fact, the city I set the film in, Kiryat Shmona, is not completely marginal in the media. Because of its geographical location, some kilometres away from the Lebanese and Syrian borders, revived tensions can strongly disrupt the ordinary. As I have mentioned elsewhere, "the particularity of life at the frontier has been recuperated, notably by Mizrahi social movements initiated by the African and Asian immigrants directed to the periphery from the 1950 s, and more largely by the Israeli right. In fact, "Israeli politicians and media further create a sense of threat, intensifying the sense of living on an exposed frontier" (Thorleifsson 2013)" (Desille, 2018, p. 448). More recently, Kiryat Shmona residents themselves have been reinvesting their collective narrative, as illustrated by the grassroots project "Memories" and the project to establish a national museum. Even though Kiryat Shmona does not always fit what the term "ordinary" could imply, it still represented a secondary urban center, an "everyday-life place" (Schnell \& Mishal, 2008), where I could study the extent to which migration structures the place.

A second dimension of my reflection concerned the people and their actions. Equipped with a camera rather than a recording device, I could capture bodies, gestures, non-oral data and material data not only on a place but also on the people that inhabited it. The recording of non-oral discourses there relates to a turn in social 
sciences, where the sensory (Pink, 2006) becomes a substantial concern. The camera enables the recording of sensory experiences; the montage, to represent it; and the screening, to invoke the senses among viewers. Additionally, and I will develop this idea more in detail in the next section, the researcher also takes part in this sensory experience. As Pink argues: "ethnography is a reflexive and experiential process through which understanding, knowing and (academic) knowledge are produced" (2009). She adds that the various works produced around senses and social sciences "draw our attention to the corporeality and multisensoriality of any social encounter or interaction - including not only the relationships between research participants but those between ethnographer and research participants" (ibid). In short, the filming process enables to act, record, represent and invoke this level of sensory experiences, through interactions between individuals (including the filming researcher and the filmed participants). In that sense, I adopted an "observational style". Observational - including direct and vérité - filmmaking has been the style of predilection of David MacDougall and Jean Rouch (Macdougall, 1998; Rouch, 1978). It focuses mainly on the subjective lives of the filmed subjects, and entails a reflexive approach by the filmmakers, which I will come back to in the section below.

In order to seize these experiences, I asked permission to film the person who would become the main character: Dr. B., an immigrant from Russia, deputy mayor of the city and in charge of immigration-related matters. We agreed upon my participation in two events. I later understood these specific time-space events, involving cultural mechanisms (e.g. ceremonies or rituals) as "vignettes" illustrating the relation between society and space, and aimed at recording how relations establish and unfold at this specific time, in this specific place. Thus, I was concerned about where and with whom the events I chose to shoot would take place. The first event was the organization of the national elections in Kiryat Shmona in March 2015, where Dr. B. was running the campaign for the national party he is a member of; and the second, the organization of the commemoration of the Second World War, in May 2015, in which he takes an active role.

A last remark I wish to make before turning to the filming itself, is that of the plot. As a matter of fact, ethnographic filmmaking, if it cannot be entirely "directed", does entail planning. In the process of imagining a scenario, I believe that, more than planning the scenes I could shoot, I mainly set rules for myself. I decided not to orally intervene, or I might say, direct, during the shooting (although in the following section, I acknowledge that my presence itself generates forms of direction). I chose to follow the main character where he goes and film interactions when they happened. This was clearly different from the in-depth encounters I organized before with Dr. B.: I did not have questions prepared to guide the conversation and he did not have lines prepared. In fact, "[w]ith film, you have to shoot events and activities at the time they occur. If you don't catch them then, they're lost forever" (Barbash \& Taylor, 1997, p. 3). A rather different situation occurred during classic interviews, where the stories are told a posteriori, and are already given coherence by the participant (Delory-Momberger, 2010; Ferrarotti, 2005).

The following section therefore addresses more in depth what happened during the shooting process. (Figs. 4.1, 4.2, 4.3, 4.4, 4.5, 4.6, 4.7 and 4.8) 


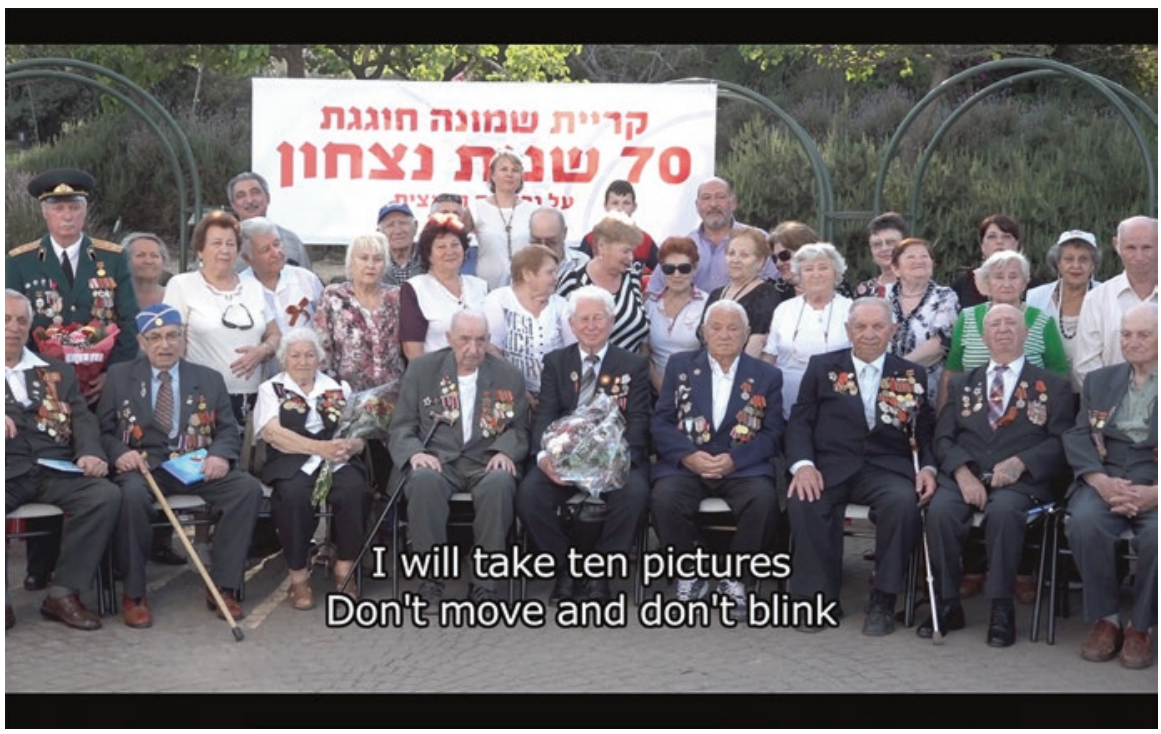

Fig. 4.1 Screenshot of the film Victory Day (Desille, 2015). The municipality of Kiryat Shmona, a city in northern Israel, organizes a memorial day for the 70th anniversary of the Victory of the Allies of WWII. At this occasion, Russian-speaking war veterans are gathering together

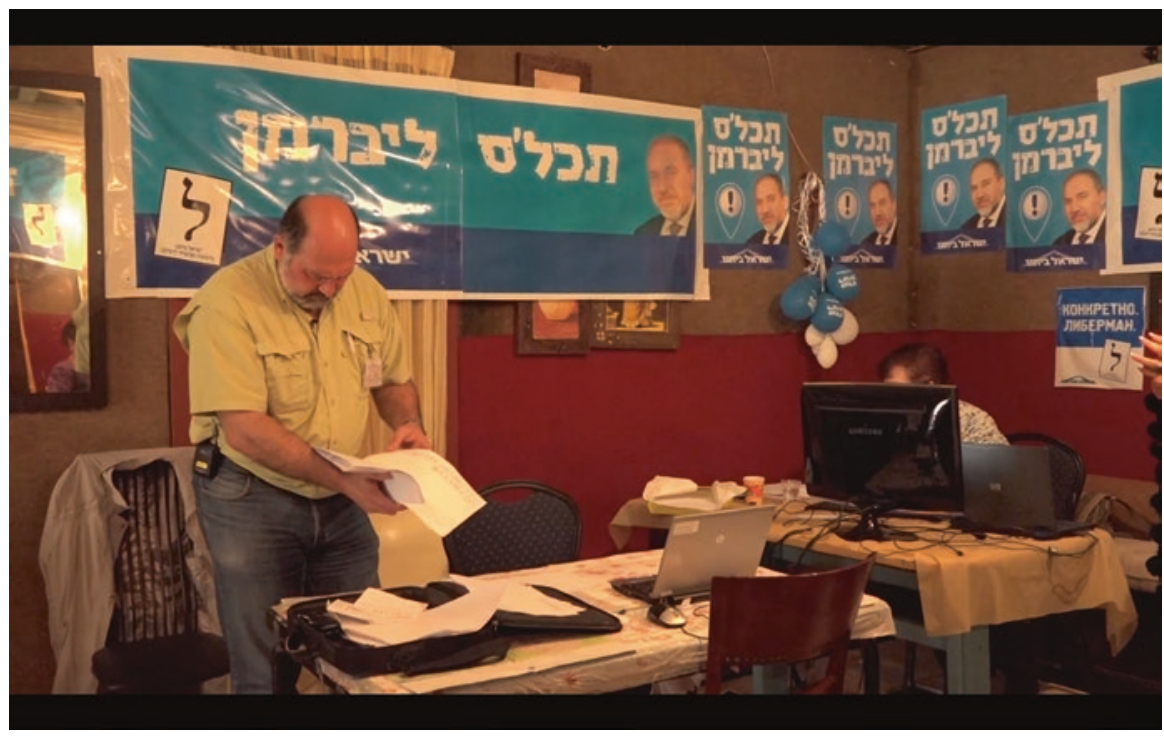

Fig. 4.2 Screenshot of the film Victory Day (Desille, 2015). On national elections' day, the deputy mayor of Kiryat Shmona, organizes the local campaign for the party he supports, Israel Beitenu. Here in the local office of the party 


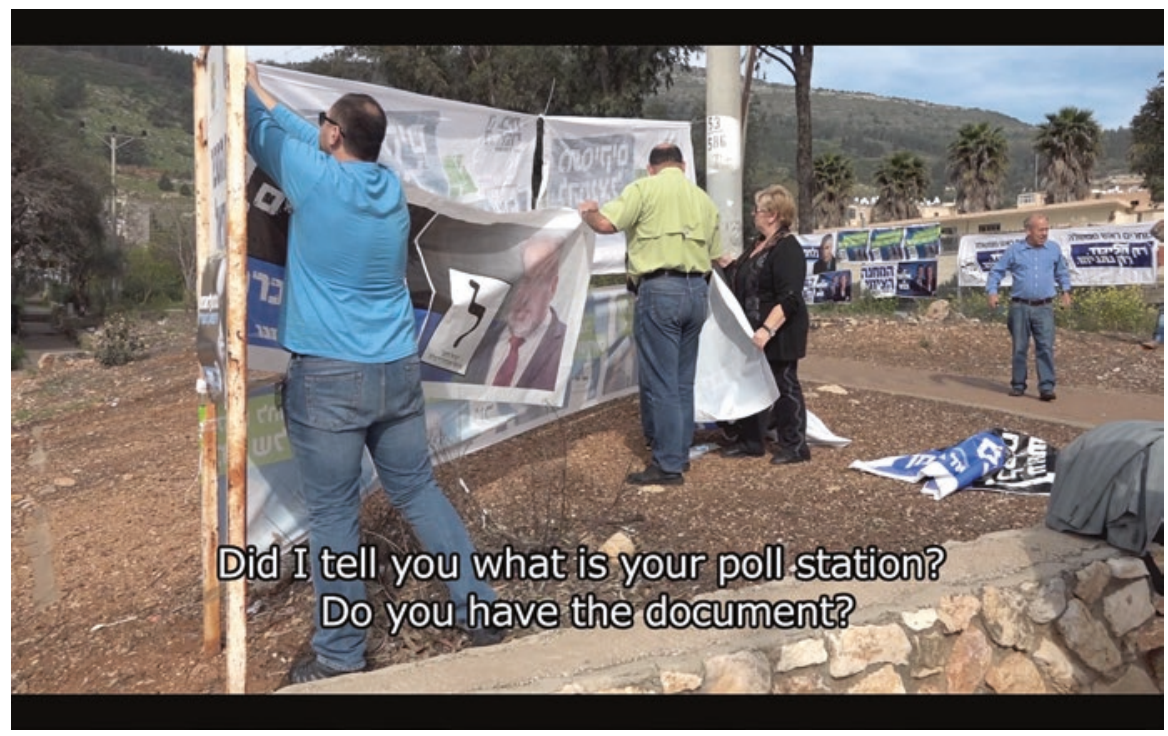

Fig. 4.3 Screenshot of the film Victory Day (Desille, 2015). Here close to a poll station

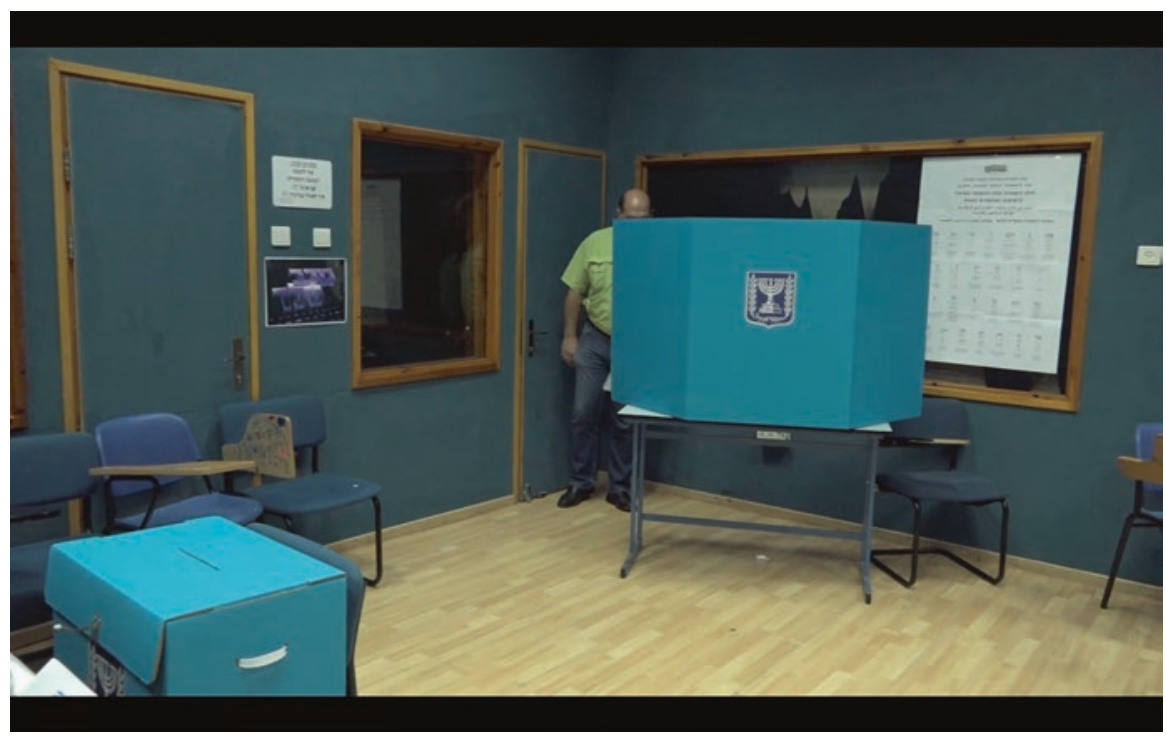

Fig. 4.4 Screenshot of the film Victory Day (Desille, 2015). Here he checks that everything is organized properly at a poll station 

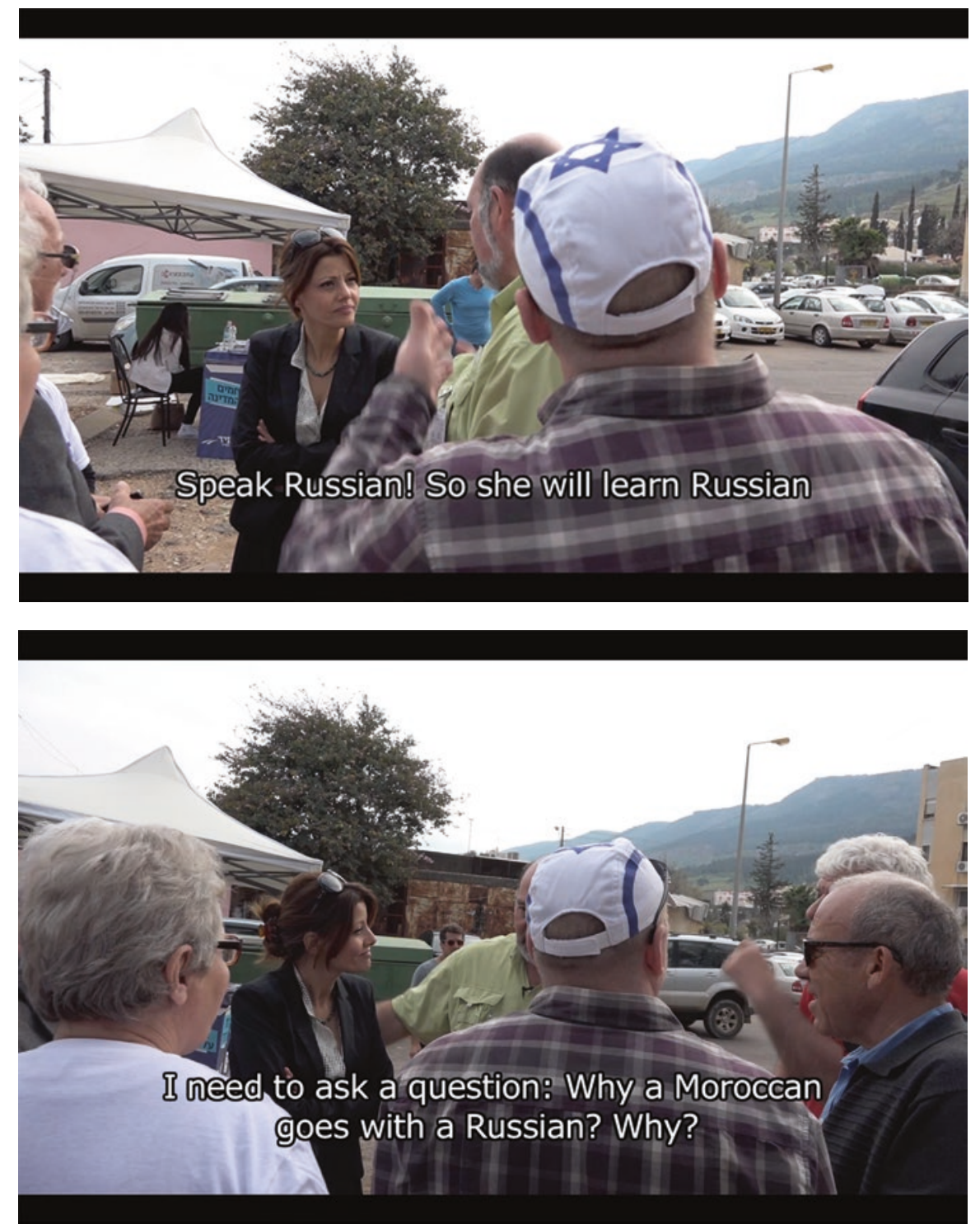

Figs. 4.5 and 4.6 Screenshots of the film Victory Day (Desille, 2015). MP Orly Levy-Abukassis is meeting with the residents of Kiryat Shmona 


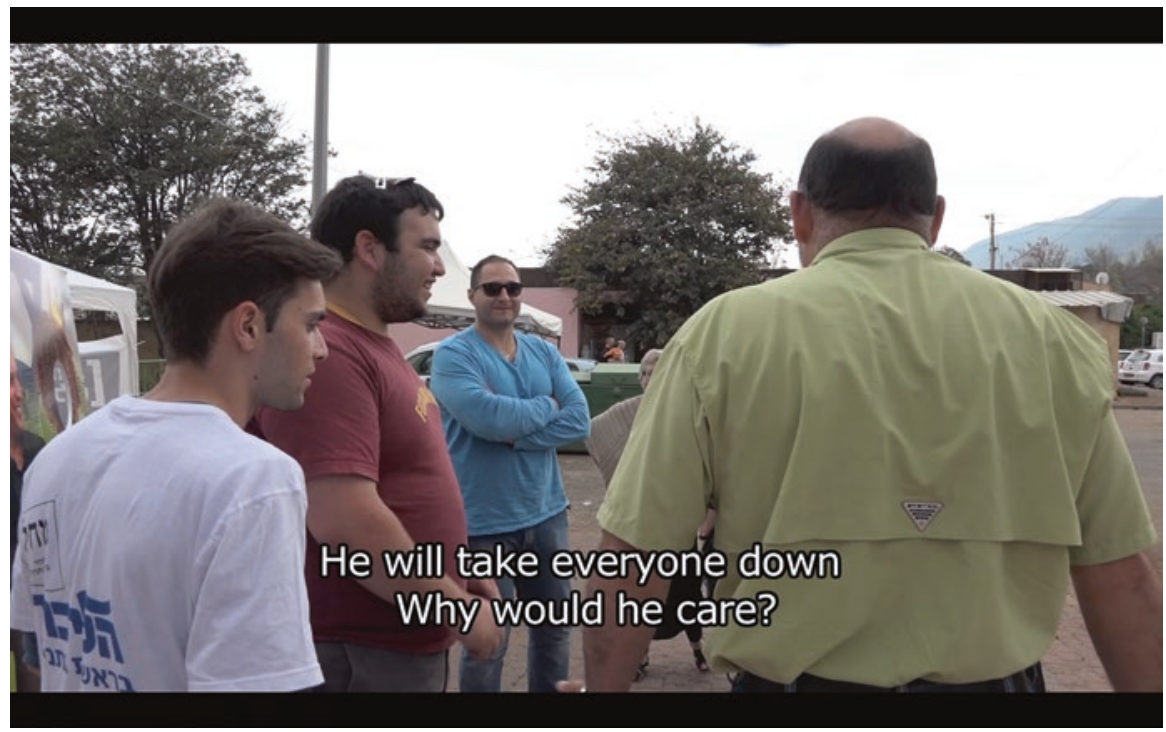

Fig. 4.7 Screenshot of the film Victory Day (Desille, 2015). Here the deputy mayor speaks with young residents about M. Putin's politics

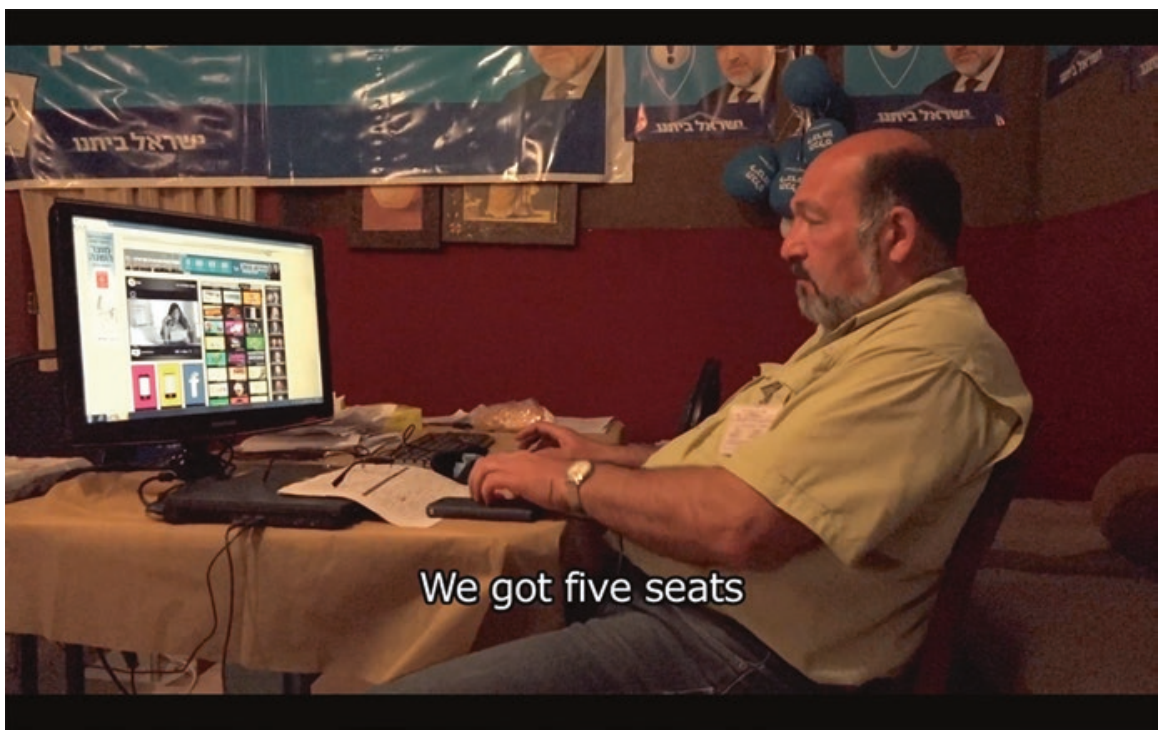

Fig. 4.8 Screenshot of the film Victory Day (Desille, 2015). Here he checks the first estimates of the results in the evening 


\subsection{Reducing the Distance?}

As mentioned in the introduction, the equipment available to researchers has become much more accessible and user friendly. However, I rented a semi-professional camera to make sure that the result will be neat and easy to edit. This "professional look" actually helped me circulating with Dr. B. As for recording the sound, I equipped Dr. B. with a neck mic, which allowed me to record all conversations and to receive his implicit authorization. Indeed, with the micro attached to his shirt, there was a tacit agreement that I would hear everything. Ball (2014), among others, has fruitfully engaged with the notion of informed consent. While this quote relates to photographs, I still believe that the neck mic played the role of the "pose":

While some photographers claim to eschew posing by subjects in their work; similarly to those social scientists aiming to uncover meaning through consent, others have pointed to the valuable role that offering the subject the opportunity to pose for a photograph can give to the overall meaning of an image. (Ball, 2014, p. 156)

The presence of the camera also provided me with an agreement from residents present around the scenes. Becker assures that "It is probably easier to be unobtrusive in public places where you are not known as an investigator and it may or may not be easier if you are carrying a camera. In many situations carrying a camera validates your right to be there; as a tourist, as a member of the group recording the scene for their purposes, or as a representative of the media" (Becker, 1974, p. 18).

My presence with the camera in hand took a different dimension than in previous encounters. "Recent discussions of phenomenological ethnography (Katz \& Csordas 2003) also insist that embodiment is "the common ground for recognition of the other's humanity and the immediacy of intersubjectivity" where the body becomes the ethnographer's research instrument (2003: 278)" (Pink, 2006, p. 46). This was brought forward by Jean Rouch, for whom cine-trance meant a triangular relation between the one filming, the camera and the ones filmed. The filmmaker, he assures, is not himself, but a mechanic eye and an electronic ear (Rouch, 1978). Rouch has not reduced the filmmaker to an absent body. On the very contrary, most of his work attempted at making the filmmaker and the filmmaking process visible to the audience. The one behind the camera and the camera itself, together, have an impact on the filmed event. What is interesting though, is that this triangular relation means that filming becomes an embodied, involved and participating experience (de Hasque, 2014). Jean-Frédéric de Hasque even coins the "dance metaphor", where the filming body, while accompanying every move of its filmed characters, "dance" with them (ibid).

Placed behind the camera, I started recording the multiple interactions created by every encounter between Dr. B. and other residents, supporters, opponents and colleagues. Dr. B. led me to them: he walks close by, stops to talk to people, aware that 
I record. Sometimes, the persons he meets on the way ask me to "take their picture", showing that they too acknowledge my presence. Through this multiplication of interactions, I started identifying the various characters that Dr. B. embodies. Seven functions, at least, were activated during the shooting. Dr. B. is an official, the deputy mayor (i) at the municipality of Kiryat Shmona. But he is also a member of the Israel Beitenu party (ii), for which he campaigns that day. With this hat, he is sometimes the head of the local bureau (iii), in competition with other party supporters, or a subaltern to other members (iv), such as MP Orly Levy Abukassis who visited Kiryat Shmona on the day of the elections. Dr. B. is also a former emergency room physician (v), and a neighbor, and he acts as such in encounters with residents. During the second shooting, Dr. B. is alternatively a conveyor (vi), facilitating community activities of the FSU group present in Kiryat Shmona; and a gatekeeper (vii) between this Russian-speaking group and the other officials of the municipality. He sometimes translates, sometimes shortens, and other times filters conversations altogether.

In the background of those scenes, the place also materializes. While we navigated into the schools (see Figs. 4.3 and 4.4), the streets, the closed restaurant where the local Israel Beitenu office was (see Figs. 4.2 and 4.8), the municipal conference room, the memorial square (see Fig. 4.1), I shot images of a city that, if present somehow in narratives, is usually visually absent. Kiryat Shmona belongs to the "new town" movement (Achouch \& Morvan, 2013; Lipshitz, 1991; Tzfadia, 2006). As the more ancient Palestinian historical core has been erased, it is a collection of residential buildings, with one of the highest percentages of public housing (Hananel, 2017) in Israel, built depending of the migration waves and the budgets allocated. These buildings are also appropriated by the residents, who often add balconies and extensions without permission. But the main interest of following him with a camera was to capture moments where he thought he was "not seen", or moments that he perceived as belonging to uninteresting shots. As such, in between the discourses he performed, with the different functions he executed, I could grasp the tiredness, doubts, and waiting time (see Fig. 4.8). Those informed even more acutely on his take on this campaign. After reading the preliminary results of the votes, Dr. B. ended this Election Day by saying out loud that he would not campaign next time, putting words to the signs of frustration I had seen during the day.

\section{4 ...or Maintaining the Distance and Refusing to "Go Native"?}

Dr. B. is a member of the national party Israel Beitenu. Established as an immigrant party, representing the large Russian speaking immigrant group who immigrated in Israel in the 1970s, and to a larger extent in the 1990s, Israel Beitenu adopted a farright, hawkish ideology. The nationalist racist ideology transpired during the shooting. Two scenes in particular clearly illustrate this stance. On the day of the election, 
a group of youngsters sit close to the party's tent, next to a polling station. Dr. B. calls them out loud and they come forward. They start commenting on their votes and Dr. B. shows his disapproval, since they haven't voted for Israel Beitenu. One asks him who would the secretary of the party M. Lieberman support, the left or the right? Dr. B. answers that M. Lieberman would support M. Putin. They laugh, and argue that it is good, since M. Putin would simply take the left down (see Fig. 4.7). Dr. B. continues: "Putin is crazy. With all the ammunition he has, he could just destroy the Arab villages around, which is really all we need". The youngsters laughed uneasily and Dr. B. turned towards me to check out if I had recorded him. However, he did not ask to lower the camera. A second scene, less obvious in its racist character, but still nationalistic, took place during the second shoot, in May 2015. In front of a small group of second World War veterans, the mayor of Kiryat Shmona, translated to Russian by Dr. B., makes a speech where he praises the actions of the veterans. He assures that their role in the victory against Nazism is actually fundamental to the establishment of Israel as a haven for Jews, and therefore, he replaces the commemoration in the broader context of Israeli nationalism. At a local level, Israel Beitenu members contribute to another form of racialization and communitarianism by feeding the Ashkenazi/Mizrahi divide ${ }^{4}$ at work in Israel. Kiryat Shmona was established in 1949 as a transit camp and since then most of its inhabitants have been Jewish immigrants from North Africa and the Middle East. ${ }^{5}$ The first opening provided by the USSR in the 1970s led to the emigration of around 350,000 Soviet Jews to Israel, many of them settling in cities such as Kiryat Shmona. But post-1989 850,000 Former Soviet Union immigrants changed the demographic composition of Kiryat Shmona even more. As of 2015, $16 \%$ of city residents were 1990s FSU immigrants. During shooting, I often recorded residents broadly (and reductively) call each other "the Russians" and "the Moroccans". This reductive approach was even clearer with the visit of MP Levy Abukassis. Herself the daughter of a prominent Moroccan-Israeli politician, she is identified as a Mizrahi representative, and her membership in a traditionally Russian-speaking party is misunderstood both by Israel Beitenu members who cannot communicate with her in Russian and by residents of Kiryat Shmona who think she should be in a party that identifies with the Mizrahi struggle (see Figs. 4.5 and 4.6). The visit of MP Levy Abukassis illustrated strongly the tension generated by the shift towards a centre/periphery ideology put in place by Israel Beitenu, and more generally, the persistence of intercommunity racism in Israel.

In this context, how should I carry out an inquiry when I cannot "go native"? Research conducted on xenophobic (Avanza, 2008) or partisan parties (Grills, 1998) presents a risk for research. In short, reducing the distance to better inquire the

\footnotetext{
${ }^{4}$ Ashkenazi is a term used to qualify Jews from Europe. Mizrahi, which means Easterner in Hebrew, has been constructed from the 1970s in Israel to include Jews from North Africa, the Middle East and Asia. It is a politico-cultural category that has enabled the formation of political parties and socio-cultural movements.

${ }^{5}$ European Jews from Poland, Hungary and Romania also established in Kiryat Shmona but were more prompt to re-migrate to regions that offered better prospects (Beenstock, 1996).
} 
everyday lives of members of Israel Beitenu holds the risk of voicing their ideas. However, being very straightforward about the opposite political stance I was taking, and showing disapproval, would risk restricting access (Cefai \& Amiraux, 2002). As Becker suggests: "If the observer gives evidence that these will not be used to harm the people he is observing, they may decide to ignore him, or to cooperate [...]". When I asked Dr. B. if I could film, he asked me if I could wear the t-shirt with the party symbol. I chose to honestly tell Dr. B. I did not support the party at all. And he chose not to see me as a threat, and allowed me to film, without wearing any sign of support.

Nevertheless, while shooting, I felt that the camera provided me with a "shield", a materialized protection to maintain distance, and enable the recording of moments that generated discomfort at best, or sometimes even blunt disapproval. As a point of fact, contrarily to interviews, where narratives are already given coherence, or observations, where coherence is given later in the field diary, the task of the visual ethnographer is to synthesize at the moment of filming (Barbash \& Taylor, 1997). I had to react promptly to capture scenes, without any possibility to go through an ethical evaluation!

The tension between the establishment of a proximity or a distance, both enabled by the use of a camera, is part of the crosscutting issues addressed in visual methodologies. As a matter of fact, bringing a camera with me both permitted me to negotiate entry in spaces, when only shadowing Dr. B. would not have been seen as a sufficient reason for him and other participants. It also allowed me to conceal my reactions and body language in situations of disapproval. In that sense, it changes my positionality and enables to negotiate new sets of intersubjectivities at the moment of filming.

Once the scenes are recorded, another set of questions arise, since it was now possible to take the time of editing and doing montage. I still refused to contribute to hawkish voices in a conflict arena, nor to the divide, or to ordinary racism. But I did not want to simplify Dr. B. to these events and produce a film which outcome would be parodic.

\subsection{Editing and Montage: Knowledge Capital and Storytelling}

At the time of planning the film, I intended to use the movie as an object to provoke conversations during encounters. The film was meant to be screened among Israelis, who knew Kiryat Shmona, its location and the challenges it faced as a periphery and a frontier city. Screening the film was meant to be a trigger to address issues of immigration, the representation of immigrants, immigrant leadership and community politics.

In that sense, I expected my audience to have enough "knowledge capital" to understand the whereabouts of the film. But while editing, I could slowly discern that I faced an accumulation of cultural references: those of the residents, of Dr. B., 
of mine (since, as Pink [2013] argues, the researcher herself brings in her own references when filming) and those of a wider non-Israeli audience. How could I take into account these differences in the knowledge the viewers will have of the city, the party and the characters?

Montage and editing were done during a workshop animated by a professor in visual anthropology, a filmmaker, and a professional editor, in which 9 other earlycareer researchers participated. The construction of the story was therefore done with the support and regular feedback of this "expert group": a first selection of scenes permitted to trigger a debate about the message conveyed in the film; the rough-cut was screened and triggered new discussions about the intelligibility of the various scenes, individually and together; and the editor helped with the final edition of the film. As Olivier de Sardan (1994) has argued in his piece "the ethnographic pact", an ethnographic film follows the following conventions: Firstly, the viewers believe that the events filmed are truthful, and that the images are "real" as they tacitly accept to forget the interpretation made while framing, making the montage and editing. Even if the images were manipulated, they keep some traces of the referential reality. Secondly, the technique aims at credibility. Victory Day respects the criteria of a slow montage, the absence of sound illusion. And thirdly, the film enables the viewer to access the representations' world of the filmed. The film is a "window on the world" and gives the viewers the feeling that they could not access this knowledge as simple tourists (ibid).

The scene selection aimed at building a story, following a classic narrative arch: the exposition corresponded to the ceremony commemorating the victory of the allies in 1945 (see Fig. 4.1). Although it was contrary to the chronology of the film shooting, the commemoration allowed a snapshot of the Russian-speaking community to be shown through a "vignette", a moment in time and in space. The import of the ceremony from the Soviet Union to Israel and the adaptation of this ceremony to the new context holds a symbolic dimension. The first scene shows children who grew up in Israel and who sing an old Russian song, adapted partly in Hebrew. They face a group of war veterans, most of them of old age, surrounding Dr. B (see Fig. 4.1). The perturbation comes when Election Day starts. The story then moves to a set of encounters between Dr. B. and residents, where a climax is reached with the visit of MP. Levy Abukassis. The story ends when the results are published in the media. Gathered at the small restaurant that serves as headquarters, Dr. B., encircled by the disappointed supporters, discovers the results of the votes and swears to stop campaigning. Images and language are established modes to represent sensory experiences (Pink, 2006, p. 58). I could rely on the power of images to describe situations. Once the scenes were selected, I had to add subtitles to the Hebrew and Russian dialogues. I had to make choices and lost certain dialogues, because of superposition. At some point, a heated debate on the inability of MP. Levy Abukassis to speak Russian becomes audible only for Russian and Hebrew speakers, while the English subtitles could support only a certain part of the debate.

After a screening at an international conference, which I will describe in the section below, I added two lines of titles - one at the beginning to explain what the commemorations were about, and one before we enter the headquarters where the campaign gets prepared, to introduce Dr. B. 


\subsection{Screening and Feedback: Shortcomings of Victory Day}

Planning, shooting and editing the film aim toward one particular moment: that of the screening to an audience. In her quest for sensory experiences, Pink comes back to this moment:

Other anthropologists have theorised the question of ethnographic film audiences and the senses by analysing Jean Rouch's films to suggest that film evokes knowledge through the viewer's own sensory experience. Stoller borrows Artaud's concept of a 'Theatre of Cruelty' whereby 'the filmmaker's goal is not to recount per se, but to present an array of unsettling images that seek to transform the audience psychologically and politically'. Defining Rouch's ethnographic films as a 'cinema of cruelty' Stoller reminds us how cinema's 'culturally coded images can at the same time trigger anger, shame, sexual excitement, revulsion, and horror' (1997: 125). (Pink, 2006, p. 52)

As a matter of fact, showing an immigrant local politician campaigning for a farright party in Israel through moving images first aimed to trigger a debate with the interviewees. On the one hand, this was a way for me to control for participation and ethics. During the research, I made a point of reporting to the municipalities where I worked on the various activities I carried out, including the film, in order to show my gratitude to the time and energy that participants spared me, but also to elude any misunderstanding regarding my interpretation of events occurring in the city. On the other hand, it held the risk, if the actors were unhappy about the result, of being manipulated ${ }^{6}$ (see for instance Olivier de Sardan, 1995; Jerome, 2008). I showed the film to Dr. B., in his office. Some weeks later, we saw it again with the mayor. The moment we saw the movie with the mayor and Dr. B. is worth mentioning. In fact, I was invited on a morning during the weekend when the office was empty. This might be a way to make sure that the outcome was not problematic. During both encounters, the film proved to be a tool to provoke a conversation, although not necessarily on the topics I expected. Both Dr. B. and the mayor check if they are photogenic and find the scenes "trivial": they affirm it is the same at every election. But while the film moves on, they both spent time telling me who is who, and what they do in the city. They comment on the scenes and the mayor gently frowns at Dr. B. for moments he finds politically incorrect.

After the screening, they discuss the question of relations between groups. But I observe a re-centering towards an institutional discourse. The film proved disruptive for a short moment only. The mayor recalls the solidarity that animated the residents of Kiryat Shmona in the 1990s and describes activities carried out at the time. Dr. B. usually so critical of the lack of policy at the municipal level, finally agrees with the mayor that immigration settlement meets with solidarity and support from the local community. I was surprised but, later on, I realized how much the moving

\footnotetext{
${ }^{6}$ Olivier de Sardan argues that because of a relation with specific actors, the others would believe that the researcher is part of a clique, of a specific local group (1995). In turn, Jerome (2008) highlights that the persons that volunteer to participate in the research are a specific group. In Jerome's research, they correspond to activists, who believe in the mediatisation of knowledge. Therefore, they have a positive bias towards the research, and accept the presence of the researcher on the ground that he or she will be instrumental to their objectives.
} 
images enabled me, at least for some hours, to distance myself from this institutional discourse that was at work within the institution. Confronting the different materials - interviewees, observations, and film - proved a great tool for comparison.

Once I received authorization from Dr. B. to show the film in academic circles, ${ }^{7}$ I showed the movie at a conference organized at Deusto University in Bilbao in July 2016. The film was part of a larger collection of students' productions. Following the screening, there were no questions or comments from the audience. Some comments made to me in private expressed the discomfort experienced by the audience. The ethno-national ideology at work triggered negative reactions, somewhat very normal! The second time it was screened was in a panel at the International Visual Sociology Association conference in Evry (France) in June 2018. At that occasion, I presented the movie together with a paper. This experience was much more positive. I got feedback from the audience and there was a real interest when I presented the movie as a data set. I also got time to explain the method and the learnings.

As Rose (2003) has suggested, it is not only the images but also the audience and the space of the "lecture theatre" that attention ought to be paid to. Maybe I felt more comfortable when making my opposition to the party more vocal and making sure the audience understood the objectives of the work. But this also showed the limitations of this film. I agree with the claim that ethnographic films are forms of publication. They are both a process of investigation and a product (Ruby, 2010). Victory Day has the ambition to be a pictorial expression of the knowledge I acquired while filming. Nevertheless, as I hope to evolve with my practice, I wish to integrate further concerns of reflexivity - not only in writing, a function this chapter has, but also in the images.

\subsection{Conclusion}

With this piece, I attempt to answer the question: how to make visible without stigmatizing? A first step was to carefully set the rules I aimed at following when realizing the film. Based on the methodology I adopted for the broader $\mathrm{PhD}$ project I carried out, I decided to focus on a less visible place and to follow the main character, adapting to this visual exercise the principles of the biographical method. I filmed with minimum oral interventions and focused on encounters with other residents, as well as moments of preparation, waiting, walking from a poll to the other and so on. At the time of editing, and with the support of peers and professionals, I aimed at exploiting the power of images and sounds to tell a story that would make sense even for persons that are not acquainted with Israeli politics.

\footnotetext{
${ }^{7}$ In the framework of my doctoral research project, I have received consent from Dr. B. to record interviews, shoot the film and use both audio and visual bits in and out of academic circles. However, since the film begins with images of children, I have decided not to display these images outside of academia, and without my presence. The screenshots selected here are of consenting adults only, including Dr. B.
} 
The interest of harnessing visual methods lies in giving a voice and making visible a group that is usually unknown. In that sense, it does fulfill questions of reciprocity, less explicit with traditional research methods. When it comes to issues linked to working in situations of political tensions, coming with a camera enables accessing different dimensions of the field while at the same time, using it as a shield when ideological distancing was crucial.

Capturing sensory experiences became more obvious at the moment of screening. Here, the value of the film - which equates a publication - is measured. In fact, it is not only about recorded images of places and people in the field, but about the narrative power of the visual production. For the audience, the senses are also invoked. Reactions of unease, discomfort, anger are part of what images can do to us. The use of visual methods differs from a text which can be ignored more easily. Understanding what is at stake in local politics in a frontier town such as Kiryat Shmona and understanding the tensions between the different groups is important to grasp a fuller picture of the regional politics, and particularly of the conflict.

However, this first exercise came with its limitations. Mostly, being engrossed in my $\mathrm{PhD}$ project, it was hard to step back and plan contextual images which could fill the knowledge gap for a less informed audience. As a matter of fact, the less visible the place, the less vocal the group, the less we know and can read between the lines. How can you create a story while avoiding the intrusion of expert voices (either as voice over, or as bits of interviews to present the problem)? A second question which in my opinion deserves further exploration is related to the inclusion of questions of reflexivity within the film, and not only in commentaries made in a written form after the edition is finalized. Thirdly, this film is also one of an outsider and it was a one-person project. The collaboration of the participants was during the shooting, while most of the editing was done by myself. Other chapters of this volume have opted for more participatory post-production processes (see Trencsényi \& Naumescu, Piemontese, MacQuarie, chaps. 7, 10 and 16, in this volume), which seems crucial for future projects.

\section{References}

Achouch, Y., \& Morvan, Y. (2013). Les utopies sionistes, des idéaux piégés par une histoire tourmentée : kiboutz et villes de développement en Israël. Utopies et Justice Spatiale, (5).

Avanza, M. (2008). Comment faire de l'ethnographie quand on n' aime pas « ses indigènes »? Une enquête au sein d'un mouvement xénophobe. In Les politiques de l'enquête (La Découverte, pp. 41-58). Paris.

Ball, S., \& Gilligan, C. (2010). Visualising migration and social division: Insights from social sciences and the visual arts. Forum Qualitative Sozialforschung/Forum: Qualitative Social Research, 11(2).

Ball, S. (2014). On the "doing" of visual research on borders and migration: Collaboration between professional photographers, social scientists and subjects. Journal of Borderlands Studies, 29(2), 147-164. https://doi.org/10.1080/08865655.2014.916066

Barbash, I., \& Taylor, L. (1997). Cross-cultural filmmaking: A handbook for making documentary and ethnographic films and videos. Berkeley, CA: University of California Press. 
Becker, H. S. (1974). Photography and sociology. Studies for visual communication, 1(1), 3-26.

Beenstock, M. (1996). Failure to absorb: remigration by immigrants into Israel. International Migration Review, 30(4), 950-978.

Burgess, J., \& Gold, J. R. (2015). Geography, the media and popular culture. Florence, Italy: Routledge.

Cefaï, D., \& Amiraux, V. (2002). Les risques du métier. Engagements problématiques en sciences sociales. Partie 1. Cultures \& Conflits, 47. https://doi.org/10.4000/conflits.829

Cresswell, T., \& Dixon, D. (2002). Engaging film: Geographies of mobility and identity. Lanham, MD: Rowman \& Littlefield.

Debord, G. (1967). La société du spectacle. Paris: Buchet/Chastel.

De Genova, N. (2013). Spectacles of migrant "illegality": The scene of exclusion, the obscene of inclusion. Ethnic and Racial Studies, 36(7), 1180-1198. https://doi.org/10.1080/0141987 0.2013 .783710

Delory-Momberger, C. (2010). La condition biographique: essais sur le récit de soi dans la modernité avancée. Paris: Téraèdre.

Desille, A. (2015). Victory Day (ethnographic film). 17 minutes.

Desille, A. (2018). Immigration and the city: Between state planning and residents' practices and representations. GeoJournal, 84, 437-457. https://doi.org/10.1007/s10708-018-9869-0

de Hasque, J. F. (2014). Corps filmant, corps dansant. Parcours anthropologiques, 9, 39-51.

Ferrarini, L. (2017). Embodied representation: Audiovisual media and sensory ethnography. Anthrovision, 5, 1. https://doi.org/10.4000/anthrovision.2514

Ferrarotti, F. (2005). On the science of uncertainty: The biographical method in social research. Lanham, MD: Lexington Books.

Gibson, J. J. (1979). The ecological approach to visual perception. London: LEA publishers.

Grills, S. (1998). On being non-partisan in partisan settings: Field research among the politically committed. In S. Grills (Ed.), Doing ethnographic research: Fieldwork settings (pp. 76-93). Newbury Park, CA: Sage.

Hananel, R. (2017). From central to marginal: The trajectory of Israel's public-housing policy. Urban Studies, 54(11), 2432-2447. https://doi.org/10.1177/0042098016649323

Hawkins, H. (2018). Geography's creative (re)turn: Toward a critical framework. Progress in Human Geography. https://doi.org/10.1177/0309132518804341

Holliday, R. (2001). Fashioning the queer self. Body dressing, 215-232.

Kennedy, C., \& Lukinbeal, C. (1997). Towards a holistic approach to geographic research on film. Progress in Human Geography, 21(1), 33-50. https://doi.org/10.1191/030913297673503066

Jérôme, L. (2008). L'anthropologie à l'épreuve de la décolonisation de la recherche dans les études autochtones : un terrain politique en contexte atikamekw. Anthropologie et Sociétés, 32(3), 179-196. https://doi.org/10.7202/029723ar

Lipshitz, G. (1991). Immigration and internal migration as a mechanism of polarization and dispersion of population and development: The Israeli case. Economic Development and Cultural Change, 39(2), 391-408.

MacDougall, D. (1998). Transcultural cinema. Princeton, NJ: Princeton University Press.

Olivier de Sardan, J.-P. (1994). Pacte ethnographique et film documentaire. Xoana, 2, 51-64.

Olivier de Sardan, J.-P. (1995). La politique du terrain. Enquête, 1. Available at: http://journals. openedition.org/enquete/263

Pauwels, L. (2010). Visual sociology reframed: An analytical synthesis and discussion of visual methods in social and cultural research. Sociological Methods \& Research, 38(4), 545-581. https://doi.org/10.1177/0049124110366233

Pink, S. (2006). The future of visual anthropology: Engaging the senses. London/New York: Routledge.

Pink, S. (2009). Doing sensory ethnography. Sage.

Pink, S. (2013). Doing visual ethnography (3rd ed.). Los Angeles: SAGE.

Raulin, A., Conord, S., Berthomière, W., Ebilitigué, I., Färber, A., Ma Mung, G., et al. (2016). Migrations et métropoles : visées photographiques. Revue Européenne des Migrations Internationales, 32(3-4), 69-130. 
Robinson, J. (2006). Ordinary cities: Between modernity and development. London/New York: Routledge.

Rouch, J. (1978). La caméra et les hommes. In Pour une anthropologie visuelle (Mouton \& EHESS). Paris/La Haye/New York: Claudine France.

Rose, G. (2003). On the need to ask how, exactly, is geography "visual"? Antipode, 35(2), 212-221. https://doi.org/10.1111/1467-8330.00317

Ruby, J. (2010). Picturing culture: Explorations of film and anthropology. Chicago, IL: Chicago University Press.

Schlottmann, A., \& Miggelbrink, J. (2009). Visual geographies - An editorial. Social Geography, 4(1), 1-11. https://doi.org/10.5194/sg-4-1-2009

Schnell, I., \& Mishal, S. (2008). Place as a source of identity in colonizing societies: Israeli settlements in Gaza. Geographical Review, 98(2), 242-259. https://doi.org/10.1111/j.19310846.2008.tb00298.x

Smith, P. D., Emmison, M., \& Mayall, M. (2000). Researching the visual. SAGE Publications Limited.

Thornes, J. E. (2004). The visual turn and geography (response to Rose 2003 intervention). Antipode, 36(5), 787-794.

Tzfadia, E. (2006). Public housing as control: Spatial policy of settling immigrants in Israeli development towns. Housing Studies, 21(4), 523-537. https://doi.org/10.1080/02673030600709058

Open Access This chapter is licensed under the terms of the Creative Commons Attribution 4.0 International License (http://creativecommons.org/licenses/by/4.0/), which permits use, sharing, adaptation, distribution and reproduction in any medium or format, as long as you give appropriate credit to the original author(s) and the source, provide a link to the Creative Commons license and indicate if changes were made.

The images or other third party material in this chapter are included in the chapter's Creative Commons license, unless indicated otherwise in a credit line to the material. If material is not included in the chapter's Creative Commons license and your intended use is not permitted by statutory regulation or exceeds the permitted use, you will need to obtain permission directly from the copyright holder.

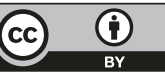

